\title{
The International Criminal Court and Africa: A fractious relationship assessed
}

\author{
Archangel Byaruhanga Rukooko* \\ Associate Professor of Philosophy and Human Rights, Makerere University, \\ Kampala, Uganda \\ https://orcid.org/0000-0002-4675-7522 \\ Jon Silverman** \\ Professor of Media and Criminal Justice, University of Bedfordshire, United \\ Kingdom \\ https://orcid.org/0000-0002-1496-9344
}

\section{Summary}

For many African states, the latest iteration of Western colonialism is the International Criminal Court. All the Court's prosecutions have involved African conflicts, and the continent's initially strong support for its creation has in recent years notably weakened. Leaders from Museveni to Kenyatta and Zuma to Bashir have excoriated the Court for its partiality, and only a change of government in The Gambia reversed a serious threat to quit its jurisdiction. Under pressure from Burundi and South Africa, the African Union has made increasingly militant noises about a mass withdrawal of member states. How should blame be apportioned for the turbulence of this relationship between the Court and the current generation of African leaders? Where does it leave a continent blighted by conflict, egregious human rights abuses and perceptions of the impunity of the 'big man' at the top? A research project, funded by the British Academy, has examined attitudes in civil society in Uganda and Kenya towards the ICC and asked whether human rights abuses could be effectively addressed by any other means. Researchers from three universities in Kenya, Uganda and the UK have interviewed judges, lawyers, NGOs, journalists and others about the ICC, domestic or regional forms of 'justice' (such as the putative African

\footnotetext{
* $\quad$ BA (Hons) (Makerere) MA (Nairobi) PhD (Makerere); rukookobe@gmail.com. This work was supported by the British Academy under International Partnership Award PM150031.

** BA (Hons) (Cambridge); Jon.Silverman@beds.ac.uk
} 
Court of Justice and Human Rights) and other transitional post-conflict mechanisms. The findings suggest that there is a high level of frustration with the performance of the ICC and, specifically, the Office of the Prosecutor. The article argues that although there is no one common denominator in the failed prosecutions, the ICC's strategy has too often yielded the initiative to long-serving leaders adept at retaining power and that, while state parties see little hope of reforming the ICC and favour an 'Africanist solution to African problems', there is little agreement on what form that should take.

Key words: International Criminal Court; justice; post-conflict; rights; colonialism; impunity

\section{Introduction}

Gathering in a plush Nairobi hotel, a group of African journalists and other civil society representatives held a one-day discussion about the International Criminal Court (ICC) and its relationship with Africa. The failed ICC prosecution of the Kenyan President, Uhuru Kenyatta, and his deputy, William Ruto, was much debated with little surprise expressed that the case had been brought to a premature close, with the Office of the Prosecutor offering no further evidence. After all, in an African setting allegations of witness intimidation shoring up presidential impunity are not exactly news.

The meeting considered the stance of the African Union (AU) which, although not a signatory to the Rome Statute, nor having a legal or institutional relationship with the ICC, has been obliged by disaffected member states to review its relationship with the Court at several summits. Three months after the Nairobi colloquium, the AU approved a non-binding resolution calling for a mass withdrawal from the ICC. ${ }^{1}$ With Kenyatta retaining power in 2017 after a violentlydisputed election; the quashing of Jean-Pierre Bemba's conviction in 2018; and the ruling in early 2019 that the former Ivory Coast President, Laurent Gbagbo, had no case to answer, the foothold of the ICC in Africa has been weakened further. This, then, is an ideal vantage point from which to shine a reflective light on the conception and application of international criminal justice, as viewed from a continent which has been the subject of every prosecution so far initiated by the Court.

While several non-governmental organisations (NGOs), academics and think-tanks have explored the pursuit of legal accountability for crimes against humanity committed in Africa, and indeed the ICC itself has not lacked self-examination on the issue, the view from

1 Reported by Reuters Africa, 1 February 2017. 
'ground level' has received less attention. ${ }^{2}$ As the Kenyan Section of the International Commission of Jurists stated, '[t]o date, there has been inadequate space for reflection by local voices on the implications of international justice in Africa and on the ICC's interventions specifically'. ${ }^{3}$

This article distils the findings of a British Academy-funded collaborative research project by the Universities of Bedfordshire (United Kingdom), Makerere in Uganda, and Nairobi, in which 30 semi-structured interviews were conducted with civil society representatives, including judges and advocates, about the ICC and other means of addressing the 'impunity gap' in Africa. ${ }^{4}$ This ethnography was supplemented by an analysis of secondary material around the themes of post-conflict justice and reconciliation on the continent. On the basis of the findings, we argue that nearly two decades of ICC intervention in Africa have failed to convince civil society that a legal remedy for crimes against humanity lies in The Hague. Notwithstanding this, in both Uganda and Kenya, the inviolability of 'big man' impunity is increasingly being challenged.

\section{Context}

At the heart of this article is the pursuit of 'justice' which, as a concept, deserves further interrogation. The roots of the term can be traced back through Latin to Greek, while both the Old and New Testaments of the Bible provide layers of interpretation. ${ }^{5}$ In the context in which we write, there are many responses to the deliberate infliction of violence. To put it somewhat mechanistically, at one end of the spectrum there is 'reciprocal mimetic violence in which perpetrators are made to suffer, even in ways similar to what they caused their victims to suffer'. ${ }^{\prime}$ At the other, there are restorative responses which form part of a wider reconciliatory process.

The foundation on which modern (that is, post-1945) international courts have been based is the Nuremberg tribunals which addressed Nazi atrocities, and we have taken that form of retributive, juridical

2 For examples, see, among others, 'Just justice? Civil society, international justice and the search for accountability in Africa' (2011) International Refugee Rights Initiative and 'The ICC intervention in Kenya' Chatham House, AFP/ILP 2013/01.

3 3rd Roundtable 'Strengthening the African human rights protection mechanisms' Mombasa, Kenya, October 2011.

4 The project has been the subject of two seminars led by the authors, in Nairobi, Kenya, October 2016 and Kampala, Uganda, January 2017. The interviews in Uganda for this study were conducted by Professor Archangel Rukooko of Makerere University. In Kenya, the interviews were carried out by Joseph Kobuthi of the University of Nairobi.

5 CF Kolbert The legal background in Justinian: The digest of Roman law - Theft, rapine, damage and insult (1979).

6 VN Redekop 'A post-genocidal justice of blessing as an alternative to a justice of violence: The case of Rwanda' in B Hart (ed) Peacebuilding in traumatised societies (2008) 206. 
response as our starting point. Nevertheless, since we are addressing African conflicts, we have not sought to ignore the importance of customary interventions claimed to be more 'culturally appropriate' in an African context, such as mato oput or Gacaca, particularly because some of the interviewees have raised objections to the ICC, precisely on the grounds that it fails to understand the African psyche, what Lajul calls 'the African social philosophy'. ${ }^{7}$ Issues of cultural difference have a special relevance to the case of Northern Uganda. ${ }^{8}$

In social science research, qualitative interviewing raises issues of epistemology. For example, what can interviewees tell us and what do they not reveal, or actively conceal? How do we analyse and assess the interview data? They also confront the questioner with the difficult question of reflexivity; in this case, a recognition that adopting a position of detached neutrality is not appropriate in the face of egregious human rights abuses. However, this does not imply a stance either of support for or opposition to the ICC, nor of any predetermined approval for arguments that 'the law should not be an instrument of cultural imperialism'. 9 While noting the frequency of 'discursive repertoires' ${ }^{\prime 10}$ such as 'neo-colonial justice', 'Western double standards' and 'race-hunting' in some of the responses and secondary sources, our inclination is to treat them as binary simplicities that are as likely to hinder inquiry as to help it.

The study has not sought to achieve an exact mathematical balance in the opinions expressed by the interviewees, nor to disqualify anyone because of their affiliation. The primary aim was to sample as wide a spread of civil society views or interpretations as possible within the time-limited scope of a modestly-funded research project. As a disclaimer, we point out that the voices of direct victims of atrocities are absent from this inquiry and certainly deserve to be heard. In addition to the people interviewed in Uganda and Kenya, two lawyers closely involved with the Kenyatta/Ruto matter were questioned. ${ }^{11}$

7 W Lajul 'Justice and post-LRA war in Northern Uganda: ICC versus Acholi traditional justice system' Paper delivered at the European Conference on Ethics, Religion and Philosophy (2016) 3.

8 See T Allen Trial justice: The International Criminal Court and the Lord's Resistance Army (2006); EK Baines 'The haunting of Alice: Local approaches to justice and reconciliation in Northern Uganda' (2007) 1 International Journal of Transitional Justice 91; A Branch 'International justice, local injustice' (2004) 51 Dissent 22.

9 T Kelsall Culture under cross-examination: International justice and the Special Court for Sierra Leone (2009) 258.

10 B Byrne 'Qualitative interviewing' in C Seale (ed) Researching society and culture (2012) 211.

11 A full list of interviewees can be found at the end of the article. 


\section{Sparring with the International Criminal Court}

A plethora of explanations have been offered for Africa's growing disaffection with the ICC. Murithi argues that African states believe that the ICC has singled out their continent because it dare not risk alienating its largest financial supporters in the global community. ${ }^{12}$ Mueller suggests that initial support for the Court was strong as long as its investigations centred on non-state actors (such as the Lord's Resistance Army (LRA)), but when the focus shifted towards former heads of state and even serving presidents, self-preservation became the dominant response. ${ }^{13}$

For Asaala, primary responsibility lies with the United Nations (UN) Security Council for being 'selective in the recognition and waiver of immunities for international crimes in favour of the interests of its permanent members'. ${ }^{14}$ On the other hand, Nel and Sibiya point out that the ICC has opened preliminary investigations in Iraq, Colombia, Afghanistan and Georgia, 'thereby dispelling the myth that the ICC only focuses on situations in Africa'. ${ }^{15}$

These assessments all have merit but it is undeniable that the issuing of an ICC warrant for the arrest of Sudanese President, Omar al-Bashir in March 2009 began the process of framing the Court as an instrument of Western colonialism, a viewpoint summed up by The Gambia's then Information Minister, Sheriff Baba Bojang, who was reported as calling the ICC 'the international Caucasian court for the persecution and humiliation of people of colour, especially Africans'. ${ }^{16}$

The indictment did not deter Bashir from successfully testing the concept of immunity by visiting Nigeria for an African Union (AU) summit in 2013 and South Africa in 2015, where the ANC-led government countermanded a court order for his arrest. The visit which provided the impetus for this research study was one to Uganda in 2016, where he attended the re-inauguration of President Museveni. At the ceremony, the Ugandan leader's attack on the ICC as 'a bunch of useless people' provoked a walkout by the ambassadors of the United States of America and Canada. ${ }^{17}$ Like South Africa, Uganda had once been a proponent of the ICC and, indeed, was the first country to refer a case (that of the Lord's Resistance Army leader, Joseph Kony) to the Court, after it came into being in 2002. However,

12 T Murithi 'Africa's relations with the ICC: A need for reorientation?' in HB Stiftung A fractious relationship: Africa and the International Criminal Court (2012) 5.

13 SD Mueller 'Kenya and the International Criminal Court: Politics, the election and the law' (2014) 8 Journal of Eastern African Studies 25.

14 EO Osaala 'Rule of law or realpolitik? The role of the United Nations Security Council in the International Criminal Court processes in Africa' (2017) 17 African Human Rights Law Journal 266.

$15 \mathrm{M} \mathrm{Nel} \&$ VE Sibiya 'Withdrawal from the International Criminal Court: Does Africa have an alternative?' (2017) 17 African Journal on Conflict Resolution 79.

16 The Guardian 27 October 2016.

17 Variously reported in Al Jazeera, allAfrica.com 13 May 2016. 
for those prepared to look, the signs were already there that leaders such as Museveni saw the Court as a means to address their own political problems rather than as a conduit to justice. Joseph Kobuthi, a member of the civil society umbrella group, Kenyans for Peace with Truth and Justice, goes right back to 1998 in his assessment: ${ }^{18}$

The decision to sign up to the Treaty of Rome by African heads of state who came to power in coups in the 1980s and 1990s was quite cynical. They saw the ICC as somewhere they could place their enemies and political opponents.

However, Museveni has seemingly inverted that proposition. Speaking at the first inauguration of Uhuru Kenyatta as Kenya's President, he congratulated Kenya's voters for rejecting 'the blackmail of the ICC' which the West used 'to install leaders of their choice in Africa and eliminate the ones they don't like'. ${ }^{19}$

From 2003, when Museveni referred the crimes of the Lord's Resistance Army in Northern Uganda to the ICC, his relationship with the Office of the Prosecutor - then occupied by the Argentinian, Luis Moreno Ocampo - reflects the old maxim: 'Keep your friends close and your enemies closer.' Indeed, the proximity was highlighted by the pair appearing at a joint press conference in London to announce the referral. The Prosecutor went on to Kampala, declaring that he would 'interpret the referral as concerning all crimes under the Rome Statute committed in Northern Uganda, leaving open the possibility of investigating alleged atrocities by government forces' ${ }^{20}$

However, despite well-documented crimes committed by the Ugandan army, the Uganda Peoples' Defence Force (UPDF), no soldier was indicted by the ICC, leading to criticism that the Prosecutor had overplayed his hand with his earlier pledge, and claims by some in the opposition that 'the ICC has become Museveni's political tool'. ${ }^{21}$

The Court of Appeal judge, Mr Justice Remmy Kasule JA, agrees that the ICC Prosecutor made a serious misjudgment in appearing alongside Museveni at the London press conference: ${ }^{22}$

By issuing the warrants of arrest [for Joseph Kony and other LRA leaders] in the company of Museveni, Ocampo gave the impression that the ICC was doing the bidding of the political leader of a country where the conflict began. This is a picture which should not have been created. Indeed, the situation became even more confusing later when the President stated publicly that he was opposed to the existence of the ICC.

18 Personal interview with researchers, October 2016.

19 Quoted by James Verini in New York Times 22 June 2016, www.nytimes.com/ 2016/06/26/magazine/international-criminal-court-moreno-ocampo-theprosecutor-and-the-president.html (accessed 20 March 2019).

20 P Clark 'Law, politics and pragmatism' in N Waddell \& P Clark (eds) Courting conflict? Justice, peace and the ICC in Africa (2008) 42.

21 As above.

22 Personal interview with researchers, October 2016. 
This somewhat instrumentalist conclusion illuminates one facet of a complicated picture. There is also the principle of complementarity, a founding tenet of the ICC, to consider. This means that if a member state is willing and capable of carrying out prosecutions itself, the ICC will not take precedence. A fellow Court of Appeal judge, Mr Justice Richard Buteera JA, argues that, albeit in a limited way, this is exactly what happened in Uganda: ${ }^{23}$

When I was Director of Public Prosecutions, some UPDF soldiers were put on trial. In fact, on one occasion, the High Court moved the proceedings to Kitgum [in Northern Uganda] to hear cases. Some soldiers were convicted of murder, rape, robbery and defilement and fired from the army. The High Court, the Uganda police and my own DPP's office made sure that sentences were served. So, yes, the ICC did not prosecute UPDF perpetrators but other institutions did.

Odong Stephen, Programme Manager for Human Rights Network Uganda (Hurinet-U), adds: ${ }^{24}$

Suppose the ICC had carried out investigations into the UPDF, would the state have co-operated? Wouldn't it have made evidence hard to find? After all, look at Kenya, where evidence and witnesses gradually disappeared until proceedings against President Kenyatta had to be stayed.

Whatever view is taken of the arrangement which underpinned the LRA indictments, there is little doubt that President Museveni showed a great deal of political finesse in his early dealings with the ICC. Perhaps encouraged by his example, fellow East African President, Uhuru Kenyatta, also demonstrated nimble footwork in forging an alliance with his erstwhile opponent, William Ruto, to fight the 2013 elections while under indictment from the ICC. This manoeuvre was not only well judged to discomfort the Office of the Prosecutor, but also to subvert the notion of 'victim-centred justice', so central to the ICC's mandate. A report by the civil society alliance, Kenyans for Peace with Truth and Justice, expressed it as follows: ${ }^{25}$

In a strange ironical reversal, Mr Kenyatta and Mr Ruto now presented themselves as victims, the hapless targets of an imperialistic plot against Africans. A plot, moreover, that would ultimately undermine democracy in Africa by blocking reconciliation efforts, such as those that the political alliance headed by Uhuru, representing the Kikuyus, and Ruto, representing the Kalenjins was purportedly trying to achieve. In turn, the ICC was cast as the pliant tool of a Western conspiracy against Kenya's sovereignty.

25 Kenyans for Peace with Truth and Justice 'Impunity restored? Lessons learned from the failure of the Kenyan cases at the International Criminal Court' 24 November 2016 5, http://kptj.africog.org/impunity-restored-lessons-learned-from-the-failureof-the-kenyan-cases-at-the-international-criminal-court/ (accessed 20 March 2019). 


\section{Harnessing the media}

In this context, becoming the first sitting head of state to stand in the dock in The Hague was not so much a high stakes gamble as an opportunity to shape the narrative which would play most effectively with a domestic audience. Harnessing the power of Kenya's highly mediatised environment was central to a 'Mugabe-ist strategy of demonising critical civil society and media voices as neo-colonial "sellouts" and "traitors". 26 Kwamchetsi Makokha writes a column for the Sunday Nation: 27

The approach by the Kenyatta government was to hold the trial anywhere but in the courtroom. In other words, to make it a trial of public opinion and, in particular, to fight the charges in our growing social media space. We've got over 30 million users of mobile phones, many of them smart phones, and it's a space which is poorly regulated and ideally suited to carrying snappy, emotive messages. No long boring articles in the newspapers but a focused social media assault. Yes, there were some newspapers and broadcast media which took the side of the ICC but the qualitative impact of the anti-coverage was far more effective.

Despite 'counter-currents in which a new Nairobi based "twitterati" utilised social media to criticise Kenyatta and Ruto and defend their prosecution', 28 the government's social media campaign was effective in discrediting civil society groups, according to Edigah Kavulavu, legal officer for the International Commission of Jurists, Kenya Section: ${ }^{29}$

These groups were seen as being in cahoots with the ICC by providing evidence for the prosecutions and there was a very effective use of Facebook and What's App to undermine their credibility. What's App is a very good tool for spreading false rumours, for example, that some of the witnesses were 'fake', in that they had been coached by Ocampo.

Thus, prefiguring the irruption of 'fake' news and 'post-truth' politics into the lexicon of the Western democracies, Kenya's media space also played host to 'pseudo' blogs and paid-for propaganda supporting the Kenyatta/Ruto camp and attacking the ICC, designed, according to Kwamchetsi Makohka,

to give the impression that they had a greater level of backing than they did. A relatively small number of people were able to make a lot of noise. Some journalists were paid to go to The Hague to cover the trials and you wonder where the resources came from, given that the media here is badly cash-strapped. ${ }^{30}$

$26 \mathrm{~K}$ Voltmer \& H Kraetzschmar 'Investigating the media and democratization conflicts' 2015 http://www.mecodem.eu/publications/working-papers (accessed 22 June 2017).

27 Personal interview with researchers, October 2016.

28 Voltmer \& Kraetschmar (n 26).

29 Personal interview with researchers, October 2016.

30 As above. 
In the interests of balance, it should be noted that this co-opting of journalists was not exclusive to the Kenyatta/Ruto side. A Kenyan journalist, who wishes to remain anonymous, told the Nairobi colloquium:

The ICC- sponsored training of journalists in Kenya, ahead of the trials, was not just teaching us about how the court operates. It was basically a form of advocacy journalism. It implied that any journalist who saw flaws in the ICC prosecution was pro-impunity. I blame the prosecutor, Ocampo, for raising expectations unreasonably.

\section{Witnesses at risk}

It will come as little surprise to anyone who has studied Kenya's media to learn that journalists are willing to accept cash for writing in support of one political interest or another. However, it is also alleged - although difficult to substantiate - that some parts of the media were used by the Kenyatta/Ruto camp to reveal the names of protected witnesses, putting their lives at risk. Ultimately, it was the unwillingness of many witnesses to repeat in oral evidence what they had previously told investigators in interviews which fatally undermined the prosecution. Irene Mutile, communications officer of the NGO Maskani Ya Taifa, says this took civil society by surprise: ${ }^{31}$

Kenyans did not expect the case to collapse due to witnesses and evidence disappearing. They thought maybe it would collapse for other reasons but not witnesses disappearing.

The ICC Prosecutor, Fatou Bensouda, complained that over half the witnesses in the case against William Ruto withdrew or retracted their initial testimony and others were killed or bribed in the Kenyatta case: ${ }^{32}$

The level of interference with those witnesses was a huge problem for the OTP. Some had members of their family threatened. We were having to protect witnesses even against their own communities and that presented a huge challenge.

However, the Kenyan advocate, Peter Kiriba, believes that the OTP could have done more to anticipate this problem: ${ }^{33}$

This is a loophole that the prosecution ought to have foreseen and sealed prior to the presentation of its case. The nature of the accused persons' [Kenyatta and Ruto] status, capability and influence should have alerted the OTP to a potential crisis and not have been left to chance.

The Irish barrister, Fergal Gaynor, represented victims of the 2007 post-election violence in the Kenyatta trial and in 2013 and 2014

31 Personal interview with researchers, September 2016.

32 Interview with 'Journalists for Justice' 21 July 2016, http://www.jfjustice.net/en/icccases/icc-chief-prosecutor-shares-thoughts-on-kenyan-cases (accessed 23 February 2017).

33 Personal interview with researchers, October 2016. 
spent 49 days interviewing 839 of these victims. He believes that an imaginative use of technology could have helped circumvent the problem of witness intimidation: ${ }^{34}$

There should be less dependence by the OTP on the oral evidence of witnesses. Where possible, investigations and prosecutions should focus on cell phone and cell site data, including SMS messages, emails and messages sent via What's App, Viber and so on between those carrying out atrocities. There's no reasonable doubt that much of this data is already being collected (if not analysed) by Western and other intelligence agencies. The difficulty is to get it to the ICC. The Special Tribunal for Lebanon has shown how billions of pieces of cell phone/cell site data can give a precise picture of what happened during the critical hours leading up to and including a major crime.

\section{Office of the Prosecutor}

Much of the criticism which followed the collapse of the Kenyatta and Ruto cases has been directed at the Office of the Prosecutor. However, it should be pointed out that, faced with an unwillingness to cooperate by a state, the ICC, which has none of the resources available to a domestic prosecutor, such as subpoenas, surveillance and policing, is at a severe disadvantage. In the Kenyatta case, requests for information from the Kenyan authorities went unanswered and the Attorney-General refused to hand over telephone, land and asset records.

However, lawyer Gary Summers, who was part of the Kenyatta defence team from August 2011 onwards, believes the Office of the Prosecutor cannot escape blame for the failure of the prosecution: ${ }^{35}$

It was amateurish. You can't just rely on human rights NGOs to find witnesses and interview them. You needed trained investigators on the ground in Kenya to check the sources of some of the allegations. The OTP relied far too heavily on the report of the Waki Commission to find witnesses. Indeed, the case against Kenyatta started with a single informant, witness no 4. The ICC needs a prosecutor who is ruthlessly focused on the target. This wasn't the case with Ocampo and frankly, Fatou Bensouda has become almost invisible.

There has been considerable criticism of Ocampo's approach. ${ }^{36}$ Edigah Kavulavu of the ICJ, Kenya Section, supported the prosecutions but remains disappointed by the way they turned out: 37

The general mood here was that we would get justice through the ICC. And that the Kenyan case would be an example to the rest of the world. But attitudes began to change when the indictments did not include Odinga and Kabaki, because their part in the PEV was well-known. The

34 E-mail from Fergal Gaynor, 12 October 2016.

35 Personal interview with researchers, October 2016. The Waki Commission was set up by the Kenyan government in 2008 to investigate the post-election violence of the previous year.

36 Verini (n 19).

37 Personal interview with researchers, October 2016. 
OTP only had a small outreach office in Nairobi, from where witnesses were interviewed. And there was no proper profiling of victims. The OTP based its judgments about witnesses/victims almost entirely on information from civil society NGOs. And, when the case finally opened in court, it was obvious that Ocampo was not trial-ready.

The ICC would argue in its defence that it achieved a historic first in getting a sitting President (Kenyatta) into court and at least dislodged a brick in the seemingly impregnable wall of impunity which has shielded African leaders from legal accountability. Bemih Kanyonge is a lawyer working for the advocacy NGO Kituo Cha Sheria (We Care for Justice): ${ }^{38}$

Politicians in Kenya are small gods. Impunity is their modus operandi. Seeing leading political figures, including the son of Kenya's founding father, in the dock at an international court humanised the political class, it made them less invincible as they had for a long time made us believe. Here was a super confident prosecutor insisting, day-in-day-out, that he had enough evidence and had made adequate preparations to effectively prosecute and provide answers for victims. At this point, impunity was certainly on a back foot.

It should be acknowledged that, although the prosecution collapsed, it was the catalyst for discussions leading to the setting up of an International Crimes Division in Kenya's High Court to make good on the promise of complementarity. However, the insistence of the prosecutor, Fatou Bensouda, that the key factor was the retraction of testimony by witnesses betrays a lack of robust strategic thinking by the ICC, which may continue to put it at a severe disadvantage when confronted by a determined state party. ${ }^{39}$

Edigah Kavulavu points out: 40

The Kenyatta/Ruto government had a well thought-out strategy: to fight the prosecution on three levels. First, to win the domestic battle of public opinion. Then, at a regional level, to gain the support of the African Union. And third, to lobby the UN Security Council that Kenyatta and Ruto were democratically elected by Kenyans and that the trial would destabilise a sensitive region of the world. Thus, by the time the prosecution collapsed, most Kenyans were relieved because they feared serious violence if Kenyatta and Ruto were convicted.

This strength of calculated resistance from a state party under indictment, where 'the government is the criminal', 41 means that the prospects of a successful prosecution are vanishingly small. As Kenyans for Peace with Truth and Justice point out: ${ }^{42}$

38 As above.

39 Fatou Bensouda interview, http://www.jfjustice.net/en/icc-cases/icc-chief-prosecu tor-shares-thoughts-on-kenyan-cases (accessed 4 March 2017).

40 Personal interview with researchers, October 2016 (Kavulavu) (n 38).

41 Verini (n 19).

42 Kenyans for Peace with Truth and Justice 'All bark no bite? State co-operation and the International Criminal Court' (2014) 24, http://kptj.africog.org/all-bark-nobite-state-cooperation-and-the-international-criminal-court/ (accessed 20 March 2019). 
The decisions, orders and requests of the Court can only be enforced by national authorities. With no enforcement agency at its disposal, the ICC cannot execute arrest warrants, compel witnesses to give testimony, collect evidence or visit the scenes where the crimes were perpetrated, without the acquiescence of national state authorities.

This, of course, is where the experience of the ICC differs from that of its ad hoc predecessors, the International Criminal Tribunal for Rwanda (ICTR) and International Criminal Tribunal for the former Yugoslavia (ICTY), mandated by the UN Security Council under chapter VII of the Charter. Both these tribunals have been regarded as 'successful' in the sense that the overwhelming majority of those indicted have been tried and convicted. However, they were dealing with conflicts that were over and peace processes signed by the time prosecutions took place. By contrast, the ICC is grappling with the ongoing geo-political turbulence of internecine and inter-state rivalries.

In Kenya's case, the prosecutor Ocampo sought to persuade the then President, Moi Kabaki and Prime Minister, Raila Odinga, to voluntarily refer the post-election violence of 2007 to the ICC. He failed and, thus, for the first time in the ICC's history, had to use his proprio motu powers to initiate an investigation. Was this a wise move? Majani Tyson, a youth, governance and human rights practitioner in Nairobi, strongly believes that it was: ${ }^{43}$

For the last few decades and even currently, massive atrocities happen without anyone being brought to book. And if one is brought to book, it is after massive damage that could have been avoided. Remember the Rwandan genocide, the Darfur conflict, the Wagalla massacre [of ethnic Somalis by Kenyan security forces in 1984] etc. All these happened due to the decision of the international community to be bureaucratic, to sit on the fence and wait for referral by state parties before intervening. To me, the decision by the ICC Prosecutor to intervene in the Kenya case was a move to encourage the international community to show a commitment to global peace and justice.

\section{Computer engineer Samuel K argues that}

[w]hether he [the Prosecutor] used his own powers without a state referral is not the issue. The issue is that our local politicians made the people believe that an external court was segregating and discriminating against them based on their ethnic affiliations. The politicians rallied behind their ethnicity and convinced people that it was the community that was being prosecuted and not the individual. ${ }^{44}$

\section{The individual or the community?}

This last insight provides a pathway to understanding one of the most significant fault lines in the fractious relationship between the ICC and Africa. Like the two ad hoc tribunals discussed earlier, the ICC was established to try crimes committed by individuals rather than states,

43 Personal interview with researchers, September 2016.

44 As above. 
notwithstanding those individuals' role in a government or a government-sanctioned agency (the International Court of Justice exists to mediate disputes between state parties).

This gave expression to the principle established at the Nuremberg tribunals that 'state agents who authorised torture or genocide against their own populations were criminally responsible in international law and might be punished by any court capable of catching them'. ${ }^{45}$

Thus, in prosecuting Uhuru Kenyatta, the ICC was addressing his individual criminal liability for crimes committed during the 2007 post-election violence, not putting the state of Kenya on trial. However, within Kenyan society Kenyatta's individuality is intimately bound up with a heritage of Kikuyu patrimonial obligations. Historically, in this patron-client arrangement

there is a shared understanding of the appropriate relationship between leaders and their communities that gave rise to complex moral economies in which rulers were expected to provide for their followers in return for their support. ${ }^{46}$

In other words, in Kenya a criminal prosecution of the patron can be presented as an attack on the clan, raising the possibility of all those dependent on the patron being deprived of material benefits and political influence if he is brought down. In these circumstances, it was all too easy for the embattled Kenyatta to make a case that, as the representative of the largest ethnic group in the country, he embodied the nation, standing resolute against an alien, Westernbacked institution, the ICC. At the (off the record) Nairobi colloquium cited earlier, two eminent civil society representatives made the same point, namely, that the Kenyatta case at the ICC was the first in which the state itself was, in effect, in the dock, and that, in these circumstances, it would mobilise every means at its disposal to thwart the prosecution. Neither speaker believed that the Office of the Prosecutor fully grasped how significant this would be.

Yet, this was not a novel challenge for an international tribunal. In the 1990s Serb politicians and military leaders, aided by a compliant domestic media, were able to present their prosecutions at the ICTY as attacks on Serbia itself. Katarina Ristić calls this perception a 'herodefendant frame', in which the accused is represented as 'sacrificing at the ICTY for the nation. Nationalist discourse transforms individual criminal charges into collective guilt accusations, in order to reject them as ungrounded. ${ }^{47}$

This is what also happened in Kenya.

45 G Robertson Crimes against humanity: The struggle for global justice (1999) xiv.

$46 \mathrm{~N}$ Cheeseman Democracy in Africa: Successes, failures and the struggle for political reform (2015) 3.

47 'Media discourses on war crimes trials in Serbia' Centre for South-East European Studies Working Paper 201246. 


\section{African solutions to an African problem?}

In 2016 the trial opened in The Hague of the former LRA commander, Dominic Ongwen, charged by the ICC with crimes against humanity. Earlier, the possibility had been mooted by both prosecution and defence, and counsel for the victims, of holding the first hearing in Gulu, Northern Uganda, where the alleged crimes had taken place. However, the judges ruled this out, citing both security and logistical concerns.

Notwithstanding the fact that some of those interviewed for this study express few qualms about justice for Africa being delivered at a distance in The Hague, there is little doubt that geographical remoteness has given impetus to criticism of the ICC by African leaders. The fact that the Court sits in the heart of Europe has also reinforced the message that prosecutions of Africans are the latest iteration of colonialism - 'new wine in old bottles', as it were. Hence, it is understandable that the AU has been searching for an 'Africanist' solution to the challenge of human rights abuses on the continent.

In 2010 the AU Commission began a process of amending the Constitutive Act of the African Court of Human and Peoples' Rights as follows: ${ }^{48}$

[T]o expand the Court's jurisdiction to include international and transnational crimes. The resultant draft protocol adds criminal jurisdiction over the international crimes of genocide, war crimes and crimes against humanity, as well as several transnational crimes, such as terrorism, piracy and corruption.

It is beyond the scope of this study to dissect the tortuous debates at AU summits and other plenary sessions about operationalising the putative AU Court of Justice and Human Rights. However, the key point of principled difference between the remit of this Court and the ICC is the issue of immunity from prosecution for a serving leader. By trying Uhuru Kenyatta and Laurent Gbagbo and indicting Bashir of Sudan, the ICC has demonstrated that, in international law, presidential impunity is dead. By contrast, the AU, meeting in Malabo, Equatorial Guinea, in 2014, declared in a protocol that as far it was concerned, immunity for a sitting president was very much alive.

As a consequence, few of the interviewees see an African court with criminal powers as an adequate answer to Africa's justice and impunity gap. Bwana Mdogo works for the Kenyan NGO Maskani Ya Taifa: ${ }^{49}$

Given the stance of the AU in supporting African heads of state (and their assistants) plus its resistance and continuous threats to withdraw from the ICC ... I highly doubt the African Court would have any teeth. And who

$48 \mathrm{M}$ du Plessis, T Maluwa \& A O'Reilly Africa and the International Criminal Court (2013) 8.

49 Personal interview with researchers, September 2016. 
knows, given the African 'big-man' culture, my fears are that it could be used to prosecute and intimidate the 'big-man's' opponents. Didn't Yoweri Museveni call upon the ICC to help him address the Joseph Kony menace in Uganda? Not to say that Kony should not be indicted of crimes against humanity, but looking at African 'big-men', which of them shouldn't be?

The budget of the proposed African Court of Justice and Human Rights, once it is operational, would undoubtedly be considerably smaller than that of the ICC, and Bemih Kanyange of Kituo Cha Sheria believes its functional capacity would be a substantial handicap: ${ }^{50}$

Yes, the court is an option, if only it had the capacity and there was political will to operationalise its increased jurisdiction. If that court was to work properly, it would be the answer to the 'African solutions to African problems' debate. However, as we know, that court is currently almost entirely funded by international development partners, capable of wielding the same influence the ICC is accused of.

Of course, this raises a number of ontological questions about what constitutes an 'Africanist solution'. Is it a question of geography where the court sits? Or, who provides the finance? After all, the largely 'successful' Special Court for Sierra Leone held the Charles Taylor trial in The Hague, with funding from only one major African donor state, Nigeria. Yet, it was not widely decried as an 'international' tribunal. In the opinion of the authors, the key issue is whether it is acknowledged in the state or region where the crimes have been committed that a measure of accountability (sufficient or not) has been achieved.

In May 2016 another way forward for trying egregious crimes in Africa came to fruition in a court in Senegal. The Extraordinary African Chambers (EAC) convicted the former President of Chad, Hissène Habré, of crimes against humanity, torture and rape. The international media (at least, those organs which take an interest in matters of justice) was euphoric.

In an editorial, the Guardian newspaper wrote that ' $[t]$ he trial of Habré has been an event without precedent. Its outcome is a watershed for human rights in Africa and beyond'. 51

This unprecedented use of the principle of universal jurisdiction to prosecute and convict the leader of one state in the courts of another was a development which many Africans thought they would never see. The financial contribution of the government of Chad towards the holding of the trial, plus its cooperation with the investigating judges during their four missions to Chad in 2013 and 2014, should not be underestimated. It is true that it took a court order from the UN to unblock the impasse which had mired the mooted prosecution in procedural difficulties for the best part of a decade, and the majority of the funding for the court process came from European

50 Personal interview with researchers, October 2016.

51 'The Guardian view on the conviction of Hissène Habré: Africa points the way' 1 June 201628. 
states. However, by the authors' own accountability standard, it must be counted as a successful African solution, not least because it was the remarkable persistence of victims' groups over two decades which made the trial a reality. Their 'reward' was the agreement by the AU to set up a trust fund for victims.

However, the implications of the Habré prosecution are clearly a threat to those $\mathrm{AU}$ leaders who fear an indictment once they leave power. Thus, it remains to be seen whether the EAC is a sui generis response to the challenge of impunity rather than a viable African alternative to the permanent blueprint offered by the ICC.

What of the much-vaunted principle of complementarity, referred to above, and the notion of the ICC as a court of last resort? When Moreno Ocampo first visited Uganda after the ICC came into force in 2002, he is said to have used the rather picaresque metaphor of the new court as an aeroplane flying over the continent of Africa, only landing if a state showed itself either incapable of or unwilling to carry out its own prosecutions. In 2008, following the Juba Peace Agreement between the Ugandan government and the Lord's Resistance Army, a war crimes division was established in the High Court (later rebranded, when Uganda adopted the International Criminal Court Act, as the International Crimes Division) which, in theory, should be capable of holding trials to an acceptable international standard. Nathan Twinomugisha was a member of Uganda's Amnesty Commission: ${ }^{52}$

The higher courts in Uganda, like the ICD, have a lot of credibility and I do believe that these courts would ably handle these cases if the international community have an interest and if they would support the ICD financially, enabling it to offer reparations. Moreover, I don't think there would be pressure from the executive, as statistics show that the government loses a higher percentage of court cases in Uganda than it wins.

A judge sitting in the International Crimes Division, Lady Justice Elizabeth Ibanda Nahamya, agrees with that assessment, but offers a caveat: 53

If Joseph Kony was arrested in Uganda, there is no reason why he shouldn't be tried here, although his atrocities are more international than merely domestic, since they spread in South Sudan and Central African Republic as well. The problem is that we do not have sufficient resources to take off. Besides, we are still grappling with just one case.

The one case she refers to is that of a former LRA commander, Thomas Kwoyelo, the first trial at the International Crimes Division, which some observers regard as a landmark test for the principle of complementarity in Africa. ${ }^{54}$ Although Kwoyelo successfully invoked

52 Personal interview with researchers, February 2017.

53 Personal interview with researchers, October 2016.

54 International Justice Monitor 13 March 2017, www.ijmonitor.org/2017/03/thethomas-kwoyelo-case-at-the-icd-issues-of-victim-participation/ (accessed $20 \mathrm{March}$ 2019). 
Uganda's amnesty law to stop the prosecution in the lower court, the decision was overturned by the Supreme Court and the trial has resumed. However, it must be said that, among those interviewed for this study - admittedly, neither a large nor necessarily representative sample - there was no abundance of confidence that domestic justice for war crimes and crimes against humanity would equate to fair and impartial justice. In 2010 a group of experts wrote to the UN Secretary-General criticising the proposition that Kenya could handle a trial of the magnitude of Kenyatta's. Dr Wandia Njoya is a lecturer at Daystar University: 55

Our problem isn't a legal capacity one: It's a political one. The politicians have a noose around the judiciary's neck. They're willing to kill and impoverish judges if they need to, and they won't be investigated because the police lack capacity and the politicians will rally support from their ethnic groups.

\section{Customs versus courts}

Those who criticise the ICC as a neo-colonial construct imposing its will on Africa, invariably make the case that for many cultures on the continent a retributive version of justice is less familiar than a reconciliatory one and, therefore, that dealing with the aftermath of conflict requires a more mixed and nuanced approach than the thud of a judicial gavel. The model often referred to is that of Rwanda, which turned to the grassroots system of justice known as Gacaca, alongside an international tribunal, to address the enormity of the 1994 genocide.

However, it sometimes is overlooked that Gacaca was an instrumental solution to a practical problem, namely, that an antiquated prison system was incapable of accommodating even a fraction of the tens of thousands of perpetrators. In Northern Uganda another customary practice, mato oput, has been championed as a more culturally acceptable alternative to the ICC. The ritual involves the sharing of a bitter liquid (oput) and a slaughtered animal, usually a sheep, by two sides in conflict, to seal reconciliation, although not necessarily forgiveness. It has been practised sporadically in the Acholi tribal territories for many generations, although opinions differ as to how widely used it is today and for what kinds of disputes.

However, there are important differences between Rwanda and Uganda. The latter is both far less centralised and far more ethnically diverse, and, whereas the genocide was confined to Rwanda itself, the Lord's Resistance Army has at various times left its imprint in South Sudan and the Central African Republic, as well as in Northern Uganda. Thus, Tim Allen of the London School of Economics, who has lived in Northern Uganda for several periods, argues that an Acholi- 
inspired practice would not be suitable for addressing the transnational crimes committed by the LRA. ${ }^{56}$

The Ugandan judge, Lady Justice Elizabeth Ibanda Nahamya, is not so dismissive of mato oput: ${ }^{57}$

It is not quite true that mato oput is specific to one region. It is also used in West Nile and Soroti, alongside other traditional justice methods to deal with all kinds of crime. But these methods cannot be equated with the ICC. Our problem in Uganda is that we have not wholly embraced informal justice. If we were to integrate it into our justice system, I believe it would be as effective because all these methods are meant to act as social controls.

Her judicial colleague, Mr Justice Remmy Kasule, argues that the retributive basis of an ICC prosecution is no different from that practised by Uganda's criminal justice system and, therefore, is widely understood, if not embraced. However, he reinforces the conceptual point made earlier that the mechanism of international criminal justice is at odds with the customary process: ${ }^{58}$

Mato oput as a trial system is more intended to establish collective guilt [of a community or clan] rather than individual guilt, unlike the ICC, where the charges and trials are of specific individuals. Traditionally, in mato oput it is the community that says 'we have done wrong' and every member, both individually and collectively, shares that wrong. However, where mato oput can be of value is after trial and sentencing, when the convicted person can be called on to show amends to the community.

The LRA delegation at the peace talks in Juba in 2007 favoured the incorporation of traditional justice methods into the formal Ugandan judicial system and for the government to challenge the jurisdiction of the ICC. ${ }^{59}$ It would require deeper inquiry to establish whether the championing of mato oput has broader support, but recognising that opinion is sharply divided about the respective merits and applicability of modern criminal justice mechanisms and traditional justice in Northern Uganda, Lajul, who has Acholi heritage, argues for a melding of the two approaches, and proposes

a type of justice that harmonises other than polarising the communities that have suffered for more than two decades. This theory is centred and guided by the view that crime that breeds injustice is more than a personal affair, it is as well a social affair. ${ }^{60}$

However, this middle way would require a paradigm shift in jurisprudential thinking at the ICC, and there is no sign that this is about to happen.

56 T Allen 'Ritual ab(use)? Problems with traditional justice in Northern Uganda' in $\mathrm{N}$ Waddell \& P Clark (eds) Courting conflict? Justice, peace and the ICC in Africa (2008) 47.

57 Personal interview with researchers, October 2016.

58 As above.

59 Allen (n 57) 51.

60 Lajul (n 7) 2 (our emphasis). 


\section{Conclusion}

In the true spirit of objective ethnography, this inquiry has eschewed a priori assumptions in favour of empirical observation. The conclusions to be drawn from the interviews are several and do not necessarily form a consistent pattern. Most of those representing what can loosely be described as human rights NGOs have argued that, for the health of society a measure of juridical accountability is necessary in order to challenge the perceived impunity of leaders and, moreover, that victims of post-conflict violence have been left on the margins of any debate about the ICC and Africa. Most believe that in theory the international criminal approach is better placed to deliver justice than domestic mechanisms because courts in Uganda and Kenya are less likely to demonstrate a robust independence from the executive. There is a similar scepticism about the potential effectiveness of a regional African Court of Justice and Human Rights. Perhaps understandably, the judges interviewed have more faith in the courtroom than do other sectors of civil society.

Scepticism turns to cynicism when questions are asked about the dealings of leaders, such as Museveni and Kenyatta, with the ICC. The consensus is that domestic political advantage is the priority for governing parties rather than a genuine commitment to addressing the results of conflict and human rights abuses. There is widespread dismay at the strategy and assumptions of the ICC, particularly of the first Prosecutor, Moreno Ocampo, in allowing forseeable obstructions, such as witness intimidation, to undermine prosecutions. The failure of the Court to do more to acknowledge perceptions of remoteness and neo-colonialism is also keenly felt on the continent.

The final thought concerns the case for African 'exceptionalism'. The haemorrhaging of support for the ICC may eventually lead to an AU-mandated court assuming responsibility for prosecuting human rights abuses. This would be a blow to the global remit of the ICC, especially if the principle of presidential immunity is maintained. However, it should never be forgotten that the ICC is a court of last resort and, in the spirit of complementarity, any means of redress for those who suffer egregious violence and abuse is surely better than none. Many of those interviewed for this study can be described as civil society gatekeepers, articulate and generally well-informed about the issues under scrutiny. What is perhaps even more urgent is to drill down further and speak to those whose lives have been irreparably scarred by man's inhumanity to man.

\section{List of interviewees}

\section{Uganda}

- Mr Justice Richard Buteera JA, Court of Appeal judge

- Simon Kaheru, lead media analyst and director, Uganda Broadcasting Corporation 
- $\quad$ Mr Justice Remmy Kasule JA, Court of Appeal judge

- Kasande Sarah Kihika, Uganda Programme Associate, International Centre for Transitional Justice

- Christopher Mbazira, Associate Professor, School of Law, Makerere University

- Peter Magala, Programme Manager for civil liberties NGO Chapter Four

- Lady Justice Elizabeth Ibanda Nahamya, judge, International Crimes Division

- Twinomugisha Nathan, Principal Legal Officer, Uganda Amnesty Commission

- Odong Stephen, Programme Manager, Human Rights Network Uganda (Hurinet-U)

- Anthony Wesak, chief court reporter, Monitor Publications

\section{Kenya}

- $\quad J a r e d$ Aol, Policy Analyst, NGO Bunge La Mwananchi

- Sharon Eshushi, Programme Manager, Sauti Yetu Debates

- $\quad$ Nahila Galole, NGO Inuka Kenya

- Chris Gitari, Executive Director, International Commission of Jurists, Kenya Section

- $\quad$ Peter Irungu, Programme Director, Inuka Kenya Trust

- $\quad$ K Samuel, computer engineer

- $\quad$ Bemih Kanyonge, Advocate, Kituo Cha Sheria

- $\quad$ Edigah Kavulavu, International Commission of Jurists, Kenya Section

- $\quad$ Vincent Kimosop, former Chairperson, Unclaimed Financial Assets

- $\quad$ Peter Kiriba, lawyer, Kiriba \& Co

- Kwamchetsi Makokha, columnist, Sunday National

- $\quad$ Bwana Mdogo, Maskani Ya Taifa

- $\quad$ Elvis Mogeni, NGO Maskani Ya Taifa

- Dismas Mokua, political analyst

- $\quad$ Irene Mutile, NGO Maskani Ya Taifa

- Wandia Njoya, lecturer, Daystar University

- Kasyoka Salim, Programme Officer, Local Development Research Institute

- Majani Tyson, Youth, Governance and Human Rights practitoner

\section{London}

- Fergal Gaynor, lawyer representing victims in Kenyatta case

- Gary Summers, lawyer, Kenyatta defence team 